\title{
Long-term use of cellular phones and brain tumours: increased risk associated with use for $\geqslant 10$ years
}

\section{Lennart Hardell, Michael Carlberg, Fredrik Söderqvist, Kjell Hansson Mild, L Lloyd Morgan}

See end of article for authors' affiliations

Correspondence to: Dr L Hardell, Department of Oncology, University Hospital, SE-701 85 Örebro, Sweden; lennart. hardell@orebroll.se

Accepted 28 March 2007 Published Online First 4 April 2007

\begin{abstract}
Aim: To evaluate brain tumour risk among long-term users of cellular telephones.
Methods: Two cohort studies and 16 case-control studies on this topic were identified. Data were scrutinised for use of mobile phone for $\geqslant 10$ years and ipsilateral exposure if presented.

Results: The cohort study was of limited value due to methodological shortcomings in the study. Of the 16 case-control studies, 11 gave results for $\geqslant 10$ years' use or latency period. Most of these results were based on low numbers. An association with acoustic neuroma was found in four studies in the group with at least 10 years' use of a mobile phone. No risk was found in one study, but the tumour size was significantly larger among users. Six studies gave results for malignant brain tumours in that latency group. All gave increased odd ratios (OR), especially for ipsilateral exposure. In a meta-analysis, ipsilateral cell phone use for acoustic neuroma was $\mathrm{OR}=2.4(95 \% \mathrm{Cl} 1.1$ to 5.3$)$ and $\mathrm{OR}=2.0$, (1.2 to 3.4) for glioma using a tumour latency period of $\geqslant 10$ years.

Conclusions: Results from present studies on use of mobile phones for $\geqslant 10$ years give a consistent pattern of increased risk for acoustic neuroma and glioma. The risk is highest for ipsilateral exposure.
\end{abstract}

O ver the past few decades, there has been rapid worldwide development of wireless technology, including increasing use of wireless telephone communication. This has raised concerns about health risks, primarily increased risk for brain tumours, owing to the proximity of the brain to the radiation antenna, with the potential for absorbing a comparatively large amount of electromagnetic energy. An increased risk for brain tumours would be an indication of other potential health effects, but it would also imply that the current guidelines for microwave exposure during phone calls are inappropriate. Initial studies on brain tumour risk had insufficiently long latency periods to give a meaningful interpretation of long-term risk. However, during recent years, studies have been published that enable evaluation of $\geqslant 10$-year latency period risk, although still mostly based on low numbers. A 10-year latency period for development of tumours seems to be a reasonable minimum period to indicate long-term carcinogenic risks from exposure to radiofrequency (RF) fields during use of cellular or cordless phones.

In this paper, we present results from cohort and casecontrol studies published to date on this topic. In tables we give 10 -year latency period results, and if presented, ipsilateral use of cellular phones, i.e. same side of tumour and microwave exposure. This gives a "worst-case scenario" that may predict increasing incidence of brain tumours in the future, as the use of cellular phones is globally widespread, with high prevalence among almost all age groups in the population. If the study did not have users with a 10-year latency period, only the overall results are presented.

The Nordic countries were among the first to introduce this new technology, and may serve as a test market for possible future health problems in other countries. The technology is briefly discussed in the following using the Swedish experience as a model.

The analogue system has been used from the early 1980s using 450 or $900 \mathrm{MHz}$ RF fields. The digital system has been increasingly used since the beginning of the 1990s and currently dominates the market. This system uses dual-band, 900 and $1800 \mathrm{MHz}$ frequencies for communication. Over recent years the third generation of mobile phones, $3 \mathrm{G}$ or universal mobile telecommunication system (UMTS), using 1,900 MHz RF fields has been introduced worldwide.

Desktop cordless phones (digital enhanced cordless telecommunications; DECT) also use wireless technology. Initially, in the late 1980s, analogue $800-900 \mathrm{MHz}$ was used but since the early 1990s, the digital $1900 \mathrm{MHz}$ system has been used. Our research group has also assessed use of DECT phones in all of our tumour investigations, whereas no such data have been presented in publications from other research groups.

\section{METHODS}

We scrutinised the literature for published studies using PubMed (www.ncbi.nlm.nih.gov) and personal knowledge of this area as we are involved in current research in this field. We used mobile/cellular/cordless telephone and brain tumour/ neoplasm/acoustic neuroma/meningioma/glioma as searching terms. If a study had several publications on certain aspects, we used the latest publication giving the most relevant data. In total, we identified 18 studies for this presentation. Two publications were cohort studies (one study analysed twice with longer follow-up) and 16 were case-control studies. No mortality studies were included. Three studies came from USA, four from Denmark, one from Finland, five from Sweden, one from the UK, one from Germany, one from Japan and two from study groups partly overlapping some of these studies.

\section{Statistical methods}

For statistical analyses, Stata V.8.2 was used (StataCorp, College Station, Texas). Random effects model was used for all meta-analyses, based on test for heterogeneity.

\section{RESULTS}

Tables 1-3 summarise the studies. The first study, by Hardell et $a l^{1{ }^{2}}$ included cases and controls from the Uppsala-Örebro

Abbreviations: DECT, digital enhanced cordless telecommunications; RF, radiofrequency; SIR, standardised incidence ratio; UMTS, universal mobile telecommunication system 
Table 1 Summary of eight studies on acoustic neuroma and use of wireless (cell) telephones

\begin{tabular}{|c|c|c|c|c|c|c|}
\hline Study & $\begin{array}{l}\text { Period } \\
\text { covered }\end{array}$ & Study type & Age (years) & $\begin{array}{l}\text { No of } \\
\text { cases }\end{array}$ & $\begin{array}{l}\mathrm{OR}^{*} \\
(95 \% \mathrm{Cl})\end{array}$ & Comments \\
\hline Inskip et al 2001, USA ${ }^{5}$ & 1994-1998 & Case-control & $\geqslant 18$ & 5 & $\begin{array}{l}1.9 \\
(0.6 \text { to } 5.9)\end{array}$ & 5 years of cell phone use \\
\hline Muscat et al 2002, USA & 1997-1999 & Case-control & $\geqslant 18$ & 11 & $\begin{array}{l}1.7 \\
(0.5 \text { to } 5.1)\end{array}$ & $3-6$ years of cell phone use \\
\hline \multirow[t]{2}{*}{$\begin{array}{l}\text { Lönn et al 2004, Sweden; } \\
\text { Interphone }^{8}\end{array}$} & \multirow[t]{2}{*}{ 1999-2002 } & \multirow[t]{2}{*}{ Case-control } & \multirow[t]{2}{*}{$20-69$} & 14 & $\begin{array}{l}1.8 \\
(0.8 \text { to } 4.3)\end{array}$ & $\begin{array}{l}\geqslant 10 \text { years since first "regular" cell phone use, result for } \\
\text { either side of head }\end{array}$ \\
\hline & & & & 12 & $\begin{array}{l}3.9 \\
(1.6 \text { to } 9.5)\end{array}$ & $\begin{array}{l}\geqslant 10 \text { years since first "regular" cell phone use on same } \\
\text { side of head as tumour }\end{array}$ \\
\hline \multirow[t]{2}{*}{$\begin{array}{l}\text { Christensen ef al 2004, } \\
\text { Denmark; Interphone }\end{array}$} & \multirow[t]{2}{*}{ 2000-2002 } & \multirow[t]{2}{*}{ Case-control } & \multirow[t]{2}{*}{$20-69$} & 45 & $\begin{array}{l}0.9 \\
(0.5 \text { to } 1.6)\end{array}$ & Regular use \\
\hline & & & & 2 & $\begin{array}{l}0.2 \\
(0.04 \text { to } 1.1)\end{array}$ & $\begin{array}{l}\geqslant 10 \text { years since first "regular" cell phone use. } \\
\text { Significantly larger tumours among cellular phone users } \\
1.66 \mathrm{~cm}^{3} \text { vs } 1.39 \mathrm{~cm}^{3}, p=0.03 \text {. }\end{array}$ \\
\hline \multirow{5}{*}{$\begin{array}{l}\text { Schoemaker et al 2005, } \\
\text { Denmark, Finland, Sweden, } \\
\text { Norway, Scotland, England; } \\
\text { Interphone" }\end{array}$} & \multirow[t]{5}{*}{ 1999-2004 } & \multirow[t]{5}{*}{ Case-control } & \multirow[t]{5}{*}{$\begin{array}{l}18-69 \\
\text { (variable) }\end{array}$} & 360 & $\begin{array}{l}0.9 \\
(0.7 \text { to } 1.1)\end{array}$ & Regular use \\
\hline & & & & 23 & $\begin{array}{l}1.8 \\
(1.1 \text { to } 3.1)\end{array}$ & $\begin{array}{l}\geqslant 10 \text { lifetime years of cell phone use on same side of } \\
\text { head as tumour }\end{array}$ \\
\hline & & & & 31 & $\begin{array}{l}1.3 \\
(0.8 \text { to } 2.0)\end{array}$ & $\begin{array}{l}\geqslant 10 \text { years since first cell phone use on same side of head } \\
\text { as tumour }\end{array}$ \\
\hline & & & & 12 & $\begin{array}{l}0.9 \\
(0.5 \text { to } 1.8)\end{array}$ & $\begin{array}{l}\geqslant 10 \text { lifetime years of cell phone use on opposite side of } \\
\text { head as tumour }\end{array}$ \\
\hline & & & & 20 & $\begin{array}{l}1.0 \\
(0.6 \text { to } 1.7)\end{array}$ & $\begin{array}{l}\geqslant 10 \text { years since first cell phone use on opposite side of } \\
\text { head as tumour }\end{array}$ \\
\hline \multirow[t]{5}{*}{ Hardell et al 2006a, Sweden ${ }^{15}$} & \multirow[t]{5}{*}{$1997-2003$} & \multirow[t]{5}{*}{ Case-control } & \multirow[t]{5}{*}{$20-80$} & 130 & $\begin{array}{l}1.7 \\
(1.2 \text { to } 2.3)\end{array}$ & $>1$-year latency of cell phone use \\
\hline & & & & 20 & $\begin{array}{l}2.9 \\
(1.6 \text { to } 5.5)\end{array}$ & $>10$-year latency of cell phone use \\
\hline & & & & 10 & $\begin{array}{l}3.5 \\
(1.5 \text { to } 7.8)\end{array}$ & $>10$-year latency of ipsilateral cell phone use \\
\hline & & & & 4 & $\begin{array}{l}1.0 \\
(0.3 \text { to } 2.9)\end{array}$ & $>10$-year latency of cordless phone use \\
\hline & & & & 3 & $\begin{array}{l}3.1 \\
(0.8 \text { to } 12)\end{array}$ & $>10$-year latency of ipsilateral cordless phone use \\
\hline Schüz et al 2006, Denmark ${ }^{17}$ & 1982-2002 & Cohort & $\geqslant 18$ & 32 & $\begin{array}{l}\mathrm{SIR}=0.7 \\
(0.5 \text { to } 1.03)\end{array}$ & $\begin{array}{l}\text { No data on latency or laterality of tumour and use of } \\
\text { mobile phone }\end{array}$ \\
\hline \multirow[t]{3}{*}{$\begin{array}{l}\text { Takebayashi et al 2006, } \\
\text { Tokyo }{ }^{18}\end{array}$} & \multirow[t]{3}{*}{ 2000-2004 } & \multirow[t]{3}{*}{ Case-control } & \multirow[t]{3}{*}{$30-69$} & 51 & $\begin{array}{l}0.7 \\
(0.4 \text { to } 1.2)\end{array}$ & Regular use \\
\hline & & & & 4 & $\begin{array}{l}0.8 \\
(0.2 \text { to } 2.7)\end{array}$ & Length of use $>8$ years \\
\hline & & & & 20 & $\begin{array}{l}0.9 \\
(0.5 \text { to } 1.6)\end{array}$ & Ipsilateral use \\
\hline
\end{tabular}

SIR, standardised incidence ratio.

*Unless otherwise stated.

region during 1994-96 and the Stockholm region during 199596 in Sweden. Only living cases were included. Two controls were selected for each case from the Swedish Population Registry. The questionnaire was answered by 217 (93\%) cases and $439(94 \%)$ controls. A high response rate was obtained because the study was hospital-based (relationship between study subjects and physicians). Two reminders were sent after the postal questionnaires if unanswered, and finally a telephone interview was conducted if possible. The population registry holds updated contact details, so it is easy to trace participants. Overall, no association between mobile phone use and brain tumours was found. However, an increased risk was seen for ipsilateral phone use, especially for tumours in the temporal, occipital or temporoparietal lobe $(\mathrm{OR}=2.4,95 \% \mathrm{CI}$ 0.97 to $6.1 .^{2}$

The study by Muscat et $a l^{3}$ included patients with malignant brain tumours from five different hospitals in USA. Controls were hospital patients and except for those from two hospitals, were not cancer patients. Data from 469 (82\%) cases and 422 $(90 \%)$ controls were available. Mean duration of use of cellular telephones was 2.8 years for cases and 2.7 years for controls. Only 17 cases $(4 \%)$ and 22 controls $(5 \%)$ had used a mobile phone for $\geqslant 4$ years. Overall, no association was found: OR $=0.9$ (95\% CI 0.6 to 1.2 ) for handheld cellular phones, and $\mathrm{OR}=2.1$ ( 0.9 to 4.7$)$ for neuroepithelioma. Of 41 assessable tumours, 26 occurred at the side of the head mostly used during calls (ipsilateral) and 15 on the contralateral side $(p=0.06)$. The study is inconclusive because no data were available on long-term users ( $\geqslant 10$-year latency period).

Johansen et al ${ }^{4}$ performed a population-based cohort study of mobile phone users in the period 1982-1995 in Denmark. In total over 700000 users were included. Subjects with phones supplied by their company (about 200 000) were excluded. Of digital (Global System for Mobile Communications; GSM) subscribers, only nine cases had used the phone for $\geqslant 3$ years. This produced a slightly increased standardised incidence ratio (SIR) of 1.2 (95\% CI 0.6 to 2.3). Digital phone users with previous use of an analogue phone yielded SIR $=1.3(0.8$ to 2.1). No subjects with 10-year use were reported.

The study by Inskip et $a l^{5}$ from the USA also had few longterm users of mobile phones: only 11 patients with glioma, 6 with meningioma and 5 with acoustic neuroma had $\geqslant 5$ years' regular use, and no subjects had $\geqslant 10$ years' use. The study enrolled 782 (92\%) hospital cases with 489 malignant brain tumours, 197 with meningioma and 96 with acoustic neuroma. Most $(80 \%)$ were interviewed within 3 weeks of diagnosis. In total, 799 (86\%) hospital-based controls were used. Regular use of mobile phones gave OR $=0.8$ (95\% CI 0.6 to 1.2 ) for glioma, $\mathrm{OR}=0.8$ (0.4 to 1.3 ) for meningioma and $\mathrm{OR}=1.0$ (0.5 to 1.9 ) for acoustic neuroma. Duration of use $\geqslant 5.0$ years did not increase the risk for glioma and meningioma, but OR increased to 1.9 (0.6 to 5.9$)$ for acoustic neuroma. Regarding different 
Table 2 Summary of nine studies on glioma and use of wireless telephones

\begin{tabular}{|c|c|c|c|c|c|c|c|}
\hline Study & $\begin{array}{l}\text { Period } \\
\text { covered }\end{array}$ & Study type & Age (years) & Tumour type & $\begin{array}{l}\text { No. of } \\
\text { cases }\end{array}$ & $\begin{array}{l}\mathrm{OR}^{*} \\
(95 \% \mathrm{CI})\end{array}$ & Comments \\
\hline Inskip et al 2001, USA & $1994-1998$ & Case-control & $\geqslant 18$ & Glioma & 11 & $\begin{array}{l}0.6 \\
(0.3 \text { to } 1.4)\end{array}$ & $\geqslant 5$ years of cell phone use \\
\hline \multirow[t]{4}{*}{ Auvinen et al 2002, Finland ${ }^{7}$} & \multirow[t]{4}{*}{1996} & \multirow[t]{4}{*}{$\begin{array}{l}\text { Case-control, } \\
\text { register-based }\end{array}$} & \multirow[t]{4}{*}{$20-69$} & \multirow[t]{4}{*}{ Glioma } & 119 & $\begin{array}{l}1.5 \\
(1.0 \text { to } 2.4)\end{array}$ & $\begin{array}{l}\text { Analogue and digital cell phone "ever" } \\
\text { use }\end{array}$ \\
\hline & & & & & 40 & $\begin{array}{l}2.1 \\
(1.3 \text { to } 3.4)\end{array}$ & Analogue cell phone "ever" use \\
\hline & & & & & 11 & $\begin{array}{l}2.4 \\
(1.2 \text { to } 5.1)\end{array}$ & Analogue cell phone use $1-2$ years \\
\hline & & & & & 11 & $\begin{array}{l}2.0 \\
(1.0 \text { to } 4.1)\end{array}$ & Analogue cell phone use, $>2$ years \\
\hline \multirow[t]{3}{*}{$\begin{array}{l}\text { Lönn et al 2005, Sweden } \\
\text { Interphone }^{10}\end{array}$} & \multirow[t]{3}{*}{$2000-2002$} & \multirow[t]{3}{*}{ Case-control } & \multirow[t]{3}{*}{$20-69$} & \multirow[t]{3}{*}{ Glioma } & 214 & $\begin{array}{l}0.8 \\
(0.6 \text { to } 1.0)\end{array}$ & Regular use \\
\hline & & & & & 15 & $\begin{array}{l}1.6 \\
(0.8 \text { to } 3.4)\end{array}$ & $\begin{array}{l}\geqslant 10 \text { years since first "regular" cell } \\
\text { phone use on same side of head as } \\
\text { tumour }\end{array}$ \\
\hline & & & & & 11 & $\begin{array}{l}0.7 \\
(0.3 \text { to } 1.5)\end{array}$ & $\begin{array}{l}\geqslant 10 \text { years since first "regular" cell } \\
\text { phone use on opposite side of head as } \\
\text { tumour. }\end{array}$ \\
\hline \multirow[t]{4}{*}{$\begin{array}{l}\text { Christensen et al } 2005 \\
\text { Denmark Interphone }^{12}\end{array}$} & \multirow[t]{4}{*}{ 2000-2002 } & \multirow[t]{4}{*}{ Case-control } & \multirow[t]{4}{*}{$20-69$} & \multirow[t]{2}{*}{$\begin{array}{l}\text { Low-grade } \\
\text { glioma }\end{array}$} & 47 & $\begin{array}{l}1.1 \\
(0.6 \text { to } 2.0)\end{array}$ & Regular use \\
\hline & & & & & 6 & $\begin{array}{l}1.6 \\
(0.4 \text { to } 6.1)\end{array}$ & $\begin{array}{l}\geqslant 10 \text { years since first "regular" use of } \\
\text { cell phone }\end{array}$ \\
\hline & & & & \multirow[t]{2}{*}{$\begin{array}{l}\text { High-grade } \\
\text { glioma }\end{array}$} & 59 & $\begin{array}{l}0.6 \\
(0.4 \text { to } 0.9)\end{array}$ & Regular use \\
\hline & & & & & 8 & $\begin{array}{l}0.5 \\
(0.2 \text { to } 1.3)\end{array}$ & $\begin{array}{l}\geqslant 10 \text { years since first regular use of cell } \\
\text { phone } \\
17 \text { ORs for high-grade glioma, all } \\
<1.0 \text {, indicate systematic bias. }\end{array}$ \\
\hline \multirow[t]{3}{*}{$\begin{array}{l}\text { Hepworth et al } 2006 \text { UK } \\
\text { Interphone }^{13}\end{array}$} & \multirow[t]{3}{*}{$2000-2004$} & \multirow[t]{3}{*}{ Case-control } & \multirow[t]{3}{*}{$18-69$} & \multirow[t]{3}{*}{ Glioma } & 508 & $\begin{array}{l}0.9 \\
(0.8 \text { to } 1.1)\end{array}$ & Regular use \\
\hline & & & & & Not given & $\begin{array}{l}1.6 \\
(0.9 \text { to } 2.8)\end{array}$ & $\begin{array}{l}\geqslant 10 \text { years of cell phone use on same } \\
\text { side of head as tumour. }\end{array}$ \\
\hline & & & & & Not given & $\begin{array}{l}0.8 \\
(0.4 \text { to } 1.4)\end{array}$ & $\begin{array}{l}>10 \text { years of cell phone use on opposite } \\
\text { side of head as tumour. }\end{array}$ \\
\hline \multirow[t]{3}{*}{$\begin{array}{l}\text { Schüz et al } 2006 \text { Germany } \\
\text { Interphone }^{14}\end{array}$} & \multirow[t]{3}{*}{ 2000-2003 } & \multirow[t]{3}{*}{ Case-control } & \multirow{3}{*}{$\begin{array}{l}30-59 \\
(2000- \\
2001), 30- \\
69(2001- \\
2003)\end{array}$} & \multirow[t]{3}{*}{ Glioma } & 138 & $\begin{array}{l}1.0 \\
(0.7 \text { to } 1.3)\end{array}$ & Regular use \\
\hline & & & & & 12 & $\begin{array}{l}2.2 \\
(0.9 \text { to } 5.1)\end{array}$ & $\begin{array}{l}\geqslant 10 \text { years since first "regular" use of } \\
\text { cell phone }\end{array}$ \\
\hline & & & & & 30 & $\begin{array}{l}2.0 \\
(1.1 \text { to } 3.5)\end{array}$ & $\begin{array}{l}\text { Female regular use of cell phone } \\
\text { (glioma, high-grade) }\end{array}$ \\
\hline \multirow[t]{10}{*}{ Hardell et al 2006b, Sweden ${ }^{16}$} & \multirow[t]{10}{*}{$1997-2003$} & \multirow[t]{10}{*}{ Case-control } & $20-80$ & $\begin{array}{l}\text { Glioma, high- } \\
\text { grade }\end{array}$ & 281 & $\begin{array}{l}1.4 \\
(1.1 \text { to } 1.8)\end{array}$ & $>1$-year latency of cell phone use \\
\hline & & & & & 71 & $\begin{array}{l}3.1 \\
(2.0 \text { to } 4.6)\end{array}$ & $>10$-year latency of cell phone use \\
\hline & & & & & 39 & $\begin{array}{l}5.4 \\
(3.0 \text { to } 9.6)\end{array}$ & $\begin{array}{l}>10 \text {-year latency of ipsilateral cell } \\
\text { phone use }\end{array}$ \\
\hline & & & & & 23 & $\begin{array}{l}2.2 \\
(1.3 \text { to } 3.9)\end{array}$ & $>10$-year latency of cordless phone use \\
\hline & & & & & 10 & $\begin{array}{l}4.7 \\
(1.8 \text { to } 13)\end{array}$ & $\begin{array}{l}>10 \text {-year latency of ipsilateral cordless } \\
\text { phone use }\end{array}$ \\
\hline & & & & $\begin{array}{l}\text { Glioma, low- } \\
\text { grade }\end{array}$ & 65 & $\begin{array}{l}1.4 \\
(0.9 \text { to } 2.3)\end{array}$ & $>1$-year latency of cell phone use \\
\hline & & & & & 7 & $\begin{array}{l}1.5 \\
(0.6 \text { to } 3.8)\end{array}$ & $>10$-year latency of cell phone use \\
\hline & & & & & 2 & $\begin{array}{l}1.2 \\
(0.3 \text { to } 5.8)\end{array}$ & $\begin{array}{l}>10-y e a r \text { latency of ipsilateral cell } \\
\text { phone use }\end{array}$ \\
\hline & & & & & 5 & $\begin{array}{l}1.6 \\
(0.5 \text { to } 4.6)\end{array}$ & $>10$-year latency of cordless phone use \\
\hline & & & & & 3 & $\begin{array}{l}3.2 \\
(0.6 \text { to } 16)\end{array}$ & $\begin{array}{l}>10 \text {-year latency of ipsilateral cordless } \\
\text { phone use }\end{array}$ \\
\hline Schüz et al 2006, Denmark ${ }^{17}$ & 1982-2002 & Cohort & $\geqslant 18$ & Glioma & 257 & $\begin{array}{l}\mathrm{SIR}=1.0 \\
(0.9 \text { to } 1.1)\end{array}$ & $\begin{array}{l}\text { No laterality of tumour and mobile } \\
\text { phone given }\end{array}$ \\
\hline & & & & & 54 & $\begin{array}{l}\mathrm{SIR}=1.2 \\
(0.9 \text { to } 1.6)\end{array}$ & Temporal lobe \\
\hline $\begin{array}{l}\text { Lahkola ef al Denmark, } \\
\text { Norway, Finland, Sweden, UK }\end{array}$ & $\begin{array}{l}\text { September } \\
2000-\end{array}$ & Case-control & $\begin{array}{l}20-69 \\
\text { (Nordic }\end{array}$ & Glioma & 867 & $\begin{array}{l}0.8 \\
(0.7 \text { to } 0.9)\end{array}$ & \\
\hline Interphone ${ }^{19}$ & $\begin{array}{l}\text { February } 2004 \\
\text { (differed } \\
\text { between } \\
\text { countries) }\end{array}$ & & $\begin{array}{l}\text { countries), } \\
18-59 \text { (UK) }\end{array}$ & & 77 & $\begin{array}{l}1.4 \\
(1.01 \text { to } \\
1.9)\end{array}$ & $\begin{array}{l}\text { Ipsilateral mobile phone use }, \geqslant 10 \text { years } \\
\text { since first use, } p \text { for trend }=0.04\end{array}$ \\
\hline
\end{tabular}

SIR, standardised incidence ratio.

*Unless otherwise stated. 
Table 3 Summary of nine studies on other brain tumour types or not specified and use of wireless telephones

\begin{tabular}{|c|c|c|c|c|c|c|c|}
\hline Study & $\begin{array}{l}\text { Period } \\
\text { covered }\end{array}$ & Study type & Age (years) & Tumour type & $\begin{array}{l}\text { No. of } \\
\text { cases }\end{array}$ & $\begin{array}{l}\mathrm{OR}^{*} \\
(95 \% \mathrm{Cl})\end{array}$ & Comments \\
\hline \multirow[t]{3}{*}{$\begin{array}{l}\text { Hardell et al 1999, } 2001 \\
\text { Sweden' }{ }^{2}\end{array}$} & 1994-1996 & Case-control & $20-80$ & Brain tumours & 78 & $\begin{array}{l}1.0 \\
(0.7 \text { to } 1.4)\end{array}$ & Analogue and digital cell phone use \\
\hline & & & & & 34 & $\begin{array}{l}1.1 \\
(0.6 \text { to } 1.8)\end{array}$ & Ipsilateral use \\
\hline & & & & & 16 & $\begin{array}{l}1.2 \\
(0.6 \text { to } 2.6)\end{array}$ & $>10$-year latency, analogue cell phone \\
\hline \multirow[t]{2}{*}{ Muscat et al 2000 USA $^{3}$} & 1994-1998 & Case-control & $18-80$ & Brain tumours & 66 & $\begin{array}{l}0.9 \\
(0.6 \text { to } 1.2)\end{array}$ & Regular use \\
\hline & & & & $\begin{array}{l}\text { Neuro- } \\
\text { epithelioma }\end{array}$ & 35 & $\begin{array}{l}2.1 \\
(0.9 \text { to } 4.7)\end{array}$ & Mean duration of use 2.8 years \\
\hline \multirow[t]{2}{*}{$\begin{array}{l}\text { Johansen et al } 2001 \\
\text { Denmark }^{4}\end{array}$} & 1982-1995 & Cohort & $>18$ & Brain tumours & 20 & $\begin{array}{l}\mathrm{SIR}=1.3 \\
(0.8 \text { to } 2.1)\end{array}$ & Analogue and digital cell phone use \\
\hline & & & & & 9 & $\begin{array}{l}\mathrm{SIR}=1.2 \\
(0.6 \text { to } 2.3)\end{array}$ & $\geqslant 3$-year duration of digital subscription \\
\hline Inskip et al 2001, USA ${ }^{5}$ & 1994-1998 & Case-control & $\geqslant 18$ & Meningioma & 6 & $\begin{array}{l}0.9 \\
(0.3 \text { to } 2.7)\end{array}$ & $\geqslant 5$ years of cell phone use \\
\hline \multirow[t]{3}{*}{$\begin{array}{l}\text { Lönn et al } 2005 \text { Sweden } \\
\text { Interphone }^{10}\end{array}$} & 2000-2002 & Case-control & $20-69$ & Meningioma & 118 & $\begin{array}{l}0.7 \\
(0.5 \text { to } 0.9)\end{array}$ & Regular use \\
\hline & & & & & 5 & 1.3 to 3.9$)$ & $\begin{array}{l}\geqslant 10 \text { years since first "regular" cell } \\
\text { phone use on same side of head as } \\
\text { tumour }\end{array}$ \\
\hline & & & & & 3 & $\begin{array}{l}0.5 \\
(0.1 \text { to } 1.7)\end{array}$ & $\begin{array}{l}\geqslant 10 \text { years since first "regular" cell } \\
\text { phone use on opposite side of head as } \\
\text { tumour. }\end{array}$ \\
\hline \multirow[t]{2}{*}{$\begin{array}{l}\text { Christensen et al } 2005 \\
\text { Denmark, Interphone }\end{array}$} & 2000-2002 & Case-control & $20-69$ & Meningioma & 67 & $\begin{array}{l}0.8 \\
(0.5 \text { to } 1.3)\end{array}$ & Regular use \\
\hline & & & & & 6 & $\begin{array}{l}1.0 \\
(0.3 \text { to } 3.2)\end{array}$ & $\begin{array}{l}\geqslant 10 \text { years since first regular use of cell } \\
\text { phone }\end{array}$ \\
\hline \multirow[t]{2}{*}{$\begin{array}{l}\text { Schüz et al } 2006 \text { Germany, } \\
\text { Interphone }^{14}\end{array}$} & 2000-2003 & Case-control & $\begin{array}{l}30-(59)- \\
69 \text { (see }\end{array}$ & Meningioma & 104 & $\begin{array}{l}0.8 \\
(0.6 \text { to } 1.1)\end{array}$ & Regular use \\
\hline & & & above) & & 5 & $\begin{array}{l}1.1 \\
(0.4 \text { to } 3.4)\end{array}$ & $\begin{array}{l}\geqslant 10 \text { years since first "regular use" of } \\
\text { cell phone }\end{array}$ \\
\hline \multirow[t]{5}{*}{$\begin{array}{l}\text { Hardell et al 2006a, } \\
\text { Sweden }^{15}\end{array}$} & 1997-2003 & Case-control & $20-80$ & Meningioma & 347 & $\begin{array}{l}1.1 \\
(0.9 \text { to } 1.3)\end{array}$ & $>1$-year latency of cell phone use \\
\hline & & & & & 38 & $\begin{array}{l}1.5 \\
10.98 \text { to } \\
2.4)\end{array}$ & $>10$-year latency of cell phone use \\
\hline & & & & & 15 & $\begin{array}{l}2.0 \\
(0.98 \text { to } \\
3.9)\end{array}$ & $\begin{array}{l}>10 \text {-year latency of ipsilateral cell } \\
\text { phone use }\end{array}$ \\
\hline & & & & & 23 & $\begin{array}{l}1.6 \\
(0.9 \text { to } 2.8)\end{array}$ & $>10$-year latency of cordless phone use \\
\hline & & & & & 9 & $\begin{array}{l}3.2 \\
(1.2 \text { to } 8.4)\end{array}$ & $\begin{array}{l}>10 \text {-year latency of ipsilateral cordless } \\
\text { phone use }\end{array}$ \\
\hline Schüz et al 2006, Denmark ${ }^{17}$ & 1982-2002 & Cohort & $\geqslant 18$ & $\begin{array}{l}\text { Brain and } \\
\text { nervous system }\end{array}$ & 28 & $\begin{array}{l}\mathrm{SIR}=0.7 \\
(0.4 \text { to } \\
0.95)\end{array}$ & $\geqslant 10$-year latency \\
\hline
\end{tabular}

SIR, standardised incidence ratio.

*Unless otherwise stated.

types of glioma, $\mathrm{OR}=1.8(0.7$ to 5.1$)$ was found for anaplastic astrocytoma.

In the study by Muscat et al, ${ }^{6}$ results were presented from a hospital based case-control study on acoustic neuroma including $90(100 \%)$ patients and $86(100 \%)$ control subjects with non-malignant diseases. Cases used a mobile phone on average for 4.1 years and controls for only 2.2 years. Use of cell phone for $1-2$ years produced $\mathrm{OR}=0.5(95 \%$ CI 0.2 to $1.3 ; \mathrm{n}=7)$, increasing to $\mathrm{OR}=1.7(0.5$ to $5.1 ; \mathrm{n}=11)$, in the group with 3-6 years' use.

A register based case-control study on brain and salivary gland tumours was performed in Finland by Auvinen et al. ${ }^{7}$ All cases aged 20-69 years diagnosed in 1996 were included, a total of 398 brain tumour cases and 34 salivary gland tumour cases. The duration of use was very short, for analogue users 2-3 years and for digital cell phone users <1 year. No association was found for salivary gland tumours. An increased risk for glioma (OR $=2.1,95 \%$ CI 1.3 to 3.4), was found for analogue phones, whereas for digital phones OR was 1.0 (0.5 to 2.0). Duration of use was used as a continuous variable and yielded for analogue phones and glioma $\mathrm{OR}=1.2$ (1.1 to 1.5 ) per year of use.

From the Karolinska Institute in Sweden, results on a casecontrol study of acoustic neuroma were reported by Lönn et al. ${ }^{8}$ Cases were identified in collaboration with hospitals and also checked with the cancer registry. Controls were randomly selected from the population registry. Exposure data were collected from 148 (93\%) cases and 604 (72\%) controls. Use of digital phones with time $\geqslant 5$ years since first use gave $\mathrm{OR}=1.2$ (95\% CI 0.7 to 2.1 ). No subjects were reported with $\geqslant 10$ years' use of a digital phone. Use of an analogue phone gave $\mathrm{OR}=1.3$ (0.6 to 2.9) for a duration of $5-9$ years, and $\mathrm{OR}=1.8(0.8$ to 4.3 ) for $\geqslant 10$ years. Ipsilateral use of a mobile phone with $\geqslant 10$ years since first use gave $\mathrm{OR}=3.9$ ( 1.6 to 9.5$)$, whereas contralateral use gave $\mathrm{OR}=0.8(0.2$ to 2.9$)$.

In Denmark a case-control study on acoustic neuroma was performed by Christensen et al. ${ }^{9}$ It comprised 106 (82\%) hospitalbased incident cases and $212(64 \%)$ population-based controls. Overall OR $=0.9$ (95\% CI 0.5 to 1.6$)$ was obtained for regular use. Time since first regular use of $\geqslant 10$ years yielded $\mathrm{OR}=0.2(0.04$ to 
1.1) based on two cases. Shorter time intervals did not increase the risk. Significantly larger tumours were found among cellular phone users: $1.66 \mathrm{~cm}^{3}$ compared with $1.39 \mathrm{~cm}^{3}$ among non-users, $\mathrm{p}=0.03$.

Lönn et $a l,{ }^{10}$ the group from the Karolinska Institute in Sweden, also performed a study on glioma and meningioma. Cases were recruited from hospitals, and controls from the population registry. Data were obtained for 371 (74\%) glioma and $273(85 \%)$ meningioma cases. The control group consisted of $674(71 \%)$ subjects. Regular phone use gave OR $=0.8(95 \%$ CI 0.6 to 1.0$)$ for glioma and $\mathrm{OR}=0.7$ (0.5 to 0.9$)$ for meningioma. Time since first regular use of $\geqslant 10$ years gave $\mathrm{OR}=1.6$ (0.8 to 3.4) for ipsilateral glioma and $\mathrm{OR}=0.7(0.3$ to 1.5) for contralateral glioma. The corresponding results were $\mathrm{OR}=1.3(0.5$ to 3.9$)$ for ipsilateral meningioma and $\mathrm{OR}=0.5$ (0.1 to 1.7 ) for contralateral meningioma.

Schoemaker et al ${ }^{11}$ presented results for acoustic neuroma as part of the Interphone study performed in six different regions in the Nordic countries and the UK. The Swedish and Danish parts have been reported previously. ${ }^{8}$ Cases were obtained from hospitals, and if possible, also from cancer registries. In the Nordic countries controls, were selected from population registries and in the UK from general practitioners' practice lists. In total, 678 (82\%) cases and 3553 (42\%) controls were interviewed. Regular use of a mobile phone yielded OR $=0.9$ (95\% CI 0.7 to 1.1 ). Lifetime use for $\geqslant 10$ years gave $\mathrm{OR}=1.8$ ( 1.1 to 3.1) for ipsilateral acoustic neuroma, and $\mathrm{OR}=0.9(0.5$ to 1.8 ) for contralateral tumour.

The Danish part of the Interphone study on brain tumours comprised $252(71 \%)$ people with glioma, 175 (74\%) with meningioma and $822(64 \%)$ controls. ${ }^{12}$ Cases were hospitalbased and controls were selected from the Danish Central Population Register. Statistical analyses gave OR $=0.8(95 \% \mathrm{CI}$ 0.5 to 1.3 ) for meningioma, $\mathrm{OR}=1.1$ (0.6 to 2.0) for low-grade glioma, and $\mathrm{OR}=0.6$ (0.4 to 0.9$)$ for high-grade glioma. Use for $\geqslant 10$ years yielded $\mathrm{OR}=1.0 \quad(0.3$ to 3.2$)$ for meningioma, $\mathrm{OR}=1.6(0.4$ to 6.1$)$ for low-grade glioma and $\mathrm{OR}=0.5(0.2$ to 1.3$)$ for high-grade glioma. For high-grade glioma 17 ORs were presented and all showed OR $<1.0$.

Hepworth $e a^{13}$ presented results from England as part of the Interphone study on glioma. It comprised 966 (51\%) cases and $1716(45 \%)$ controls. Cases were ascertained from multiple sources including hospital departments and cancer registries. The controls were randomly selected from general practitioners' lists. The overall OR for regular phone use was 0.9 (95\% CI 0.8 to 1.1$)$. Ipsilateral phone use was $\mathrm{OR}=1.2$ (1.02 to 1.5$)$, and contralateral $\mathrm{OR}=0.8(0.6$ to 0.9$)$. Ipsilateral use for $\geqslant 10$ years produced $\mathrm{OR}=1.6(0.9$ to 2.8$)$, and contralateral $\mathrm{OR}=0.8(0.4$ to 1.4 ).

The Interphone Study Group with Schüz et al ${ }^{14}$ from Germany presented results for glioma and meningioma. Incident cases from four different neurosurgery clinics were included. The results were based on interviews of 366 (80\%) glioma cases and $381(88 \%)$ meningioma cases. Controls were randomly selected from population registries, and in total 1494 (61\%) were included in the analyses. Overall, no association was found between use of cellular telephones and brain tumour. For glioma OR $=1.0$ (95\% CI 0.7 to 1.3 ), and for meningioma $\mathrm{OR}=0.8$ (0.6 to 1.1$)$, were obtained. However, for users of cellular telephones for $\geqslant 10$ years $\mathrm{OR}=2.2(0.9$ to 5.1$)$ was calculated for glioma and $\mathrm{OR}=1.1$ (0.4 to 3.4) for meningioma. For women with "ever" use of a cell phone OR $=2.0$ ( 1.1 to 3.5 ) was calculated for high-grade glioma.

Our group ${ }^{15}$ reported in a pooled analysis the results for benign brain tumours from two case-control studies. Cases were reported from Cancer Registries and controls were population-based. The questionnaire was answered by 1254
$(88 \%)$ cases and $2162(89 \%)$ controls. Use of cordless desktop phones was assessed. Use of cellular phones gave for acoustic neuroma $\mathrm{OR}=1.7$ (95\% CI 1.2 to 2.3 ), and cordless phones $\mathrm{OR}=1.5$ ( 1.04 to 2.0 ). Using a $>10$-year latency period for cellular telephones gave $\mathrm{OR}=2.9$ ( 1.6 to 5.5$)$, and cordless phones $\mathrm{OR}=1.0(0.3$ to 2.9$)$. Results were also presented for analogue and digital cellular telephones separately. In a multivariate unconditional regression analysis using $>10$-year latency period, only analogue phones were significant risk factors, $\mathrm{OR}=2.2$ ( 1.3 to 3.8$)$. For meningioma, cellular phones gave $\mathrm{OR}=1.1(0.9$ to 1.3$)$ and cordless $\mathrm{OR}=1.1(0.9$ to 1.4$)$. Using a >10-year latency period, ORs increased: for cellular telephones OR $=1.5$ (0.98 to 2.4), and for cordless phones $\mathrm{OR}=1.6$ (0.9 to 2.8). Ipsilateral exposure gave $\mathrm{OR}=2.0(0.98$ to 2.9) for cellular phones, and $\mathrm{OR}=3.2$ ( 1.2 to 8.4 ) for cordless phones in the $>10$-year latency group. In the multivariate analysis, neither cellular nor cordless phones were significant risk factors for meningioma. Also for meningioma, results were reported for both analogue and digital cell phones.

Our later study $^{16}$ presented results for malignant brain tumours. Answers were obtained from 905 (90\%) cases, and the same control group as for benign tumours was used (2162; $89 \%)$. Overall, the study found for low-grade astrocytoma $\mathrm{OR}=1.4$ (95\% CI 0.9 to 2.3 ) for cellular phones and $\mathrm{OR}=1.4$ (0.9 to 3.4 for) cordless phones. The corresponding results for

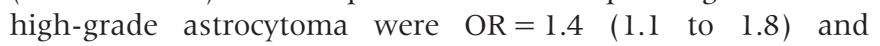
$\mathrm{OR}=1.5$ ( 1.1 to 1.9 ), respectively. Using a $>10$-year latency period gave results for low-grade astrocytoma of OR $=1.5(0.6$ to 3.8 ) for use of cellular phones (ipsilateral $\mathrm{OR}=1.2,0.3$ to $5.8)$, and $\mathrm{OR}=1.6(0.5$ to 4.6$)$ for cordless phones (ipsilateral $\mathrm{OR}=3.2,0.6$ to 16$)$. For high-grade astrocytoma in the same latency period, cellular phones had $\mathrm{OR}=3.1$ (2.0 to 4.6) (ipsilateral $\mathrm{OR}=5.4, \quad 3.0$ to 9.6), and cordless phones $\mathrm{OR}=2.2$ (1.3 to 3.9) (ipsilateral $\mathrm{OR}=4.7,1.8$ to 13$)$. The multivariate analysis of high-grade astrocytoma gave $\mathrm{OR}=2.2$ ( 1.6 to 3.1) for cellular phones, and $\mathrm{OR}=1.3(0.8$ to 2.3 ) cordless phones, with a $>10$-year latency period. Results were also presented for analogue and digital phones separately.

The Danish cohort study on mobile phone subscribers ${ }^{4}$ was updated with follow-up through 2002 for cancer incidence. ${ }^{17}$ As previously, >200 000 (32\%) company subscribers were excluded and apparently instead included in the population-based comparison group. The expected numbers were based on the general population. However, a large part of the population does use mobile phones and/or cordless phones, the latter use not assessed at all in the study. There was no truly unexposed group for comparison. Of the subscribers, $85 \%$ were men and $15 \%$ were women, thus giving a very skewed sex distribution. There seemed to be a "healthy worker" effect in the study, as SIR was significantly decreased to 0.95 (95\% CI 0.9 to 0.97 ) for all cancers. In the group with $\geqslant 10$ years since first subscription, significantly decreased SIR of 0.7 (0.4 to 0.95 ) was found for brain and nervous system tumours indicating methodological problems in the study. Temporal glioma yielded SIR $=1.2$ (0.9 to 1.6). This finding was based on 54 people. No latency data were given or laterality of phone use in relation to tumour localisation in the brain.

As part of the Interphone study a case-control study was performed on acoustic neuroma in Tokyo. ${ }^{18}$ The cases were recruited from hospitals including 23 wards and controls using random digit dialling. Of 120 eligible cases, 101 (84\%) participated in the study. In total, 647 controls were selected but only 339 (52\%) were interviewed. Regular mobile phone use yielded $\mathrm{OR}=0.7$ (95\% CI 0.4 to 1.2 ). For use $>8$ years $\mathrm{OR}=0.8$ (0.2 to 2.7) was obtained. A somewhat increased risk was found for 300-900 hours cumulative call time, with $\mathrm{OR}=1.4(0.5$ to 3.5$)$. The $>900$ hours group gave $\mathrm{OR}=0.7$ (0.3 to 1.8$)$. No effect of laterality was seen, ipsilateral mobile 
phone use $\mathrm{OR}=0.9(0.5$ to 1.6$)$, and contralateral use $\mathrm{OR}=0.9$ (0.6 to 1.6$)$.

A report on mobile phone use and risk of glioma in Denmark, and parts of Finland, Norway, Sweden and UK gave summary results for these Interphone studies. ${ }^{19}$ In the report, three previously published studies were included from Sweden, ${ }^{10}$ Denmark $^{12}$ and the UK. ${ }^{13}$ Of 2530 eligible cases, 1521 (60\%) participated. Overall, no increased risk was found for regular mobile phone use, OR $=0.8$ (95\% CI 0.7 to 0.9). However, cumulative hours of use gave OR $=1.006$ ( 1.002 to 1.010 ) per 100 hours. For $\geqslant 10$ years, $O R=1.4$ ( 1.01 to 1.9$)$, $p$ for trend $=0.04$ was found for ipsilateral mobile phone use. Contralateral use gave $\mathrm{OR}=1.0$ (0.7 to 1.4 ) in the same group.

Using a latency period of $\geqslant 10$ years (for definitions see tables) we performed a meta-analysis of the risk for acoustic neuroma, glioma and meningioma. For acoustic neuroma in the total group, OR $=1.3(95 \%$ CI 0.6 to 2.8$)$ was obtained, ${ }^{8} 91115$ and for ipsilateral mobile phone use $\mathrm{OR}=2.4$ ( 1.1 to 5.3 ) was calculated. ${ }^{811}{ }^{15}$ For glioma, OR $=1.2$ (0.8 to 1.9) was calculated in the whole group ${ }^{10-14}{ }^{16}{ }^{19}$ increasing to $\mathrm{OR}=2.0$ (1.2 to 3.4) for ipsilateral use. $^{10131619}$ The corresponding results for meningioma were $\mathrm{OR}=1.3(0.9 \text { to } 1.8)^{10121415}$ and $\mathrm{OR}=1.7$ $(0.99 \text { to } 3.1)^{10}{ }^{15}$ respectively.

\section{DISCUSSION}

This review included 18 studies: 2 cohort and 16 case-control studies. Some of the studies were part of the Interphone investigation and two publications included results from different studies. ${ }^{11}{ }^{19}$ The conclusions on the risk for brain tumours associated with use of cellular phones have to date been based mostly on studies with an insufficiently long latency period in carcinogenesis. As we are now seeing results from studies with long-term users (i.e. $\geqslant 10$ years), it is pertinent to compile the data to see if a pattern of association with brain tumours is emerging. It should be noted that only the studies by our group ${ }^{15}{ }^{16}$ also give results for use of cordless phones. It is necessary to assess such use in case-control studies, which has been discussed in our publications, thus, an association between cordless phones and brain tumours is not discussed further here.

Of the 16 case-control studies, 11 gave results for $\geqslant 10$ years' use or latency period. Most of these results were based on low numbers, as can be seen from the tables. Brain tumours are a heterogenic group of tumours including both malignant and benign types. Thus, it is reasonable to separate the results for malignant and benign tumours, as has been carried out in the various studies. The Danish cohort study ${ }^{4}$ is not very informative, owing to the limits in study design, analysis and follow-up, and will not be discussed further. The same methodological limitations are present in the updated version. ${ }^{17}$

Acoustic neuroma might be a "signal" tumour type for increased brain tumour risk from microwave exposure, as it is located in an anatomical area that receives high exposure during calls with cellular or cordless phones. In fact, an increasing incidence of acoustic neuroma has been noted in Sweden. ${ }^{20}$ In table 1, results are presented from seven case-control studies on acoustic neuroma and use of cellular phones. Three studies ${ }^{5} 18$ did not have follow-up of at least 10 years, but two of them showed a somewhat increased risk for shorter latency periods. Three of the four studies with data on $\geqslant 10$ years' use showed a statistically significantly increased risk overall or for ipsilateral exposure to microwaves. In one study, no association was found but the result was based on only two cases. ${ }^{9}$ The tumours were significantly larger among mobile phone users. In our previous study, ${ }^{15}$ an increased risk was also found with a shorter latency period. The mechanism for the increased risk for acoustic neuroma from microwave exposure is unknown. An effect might exist at different stages in tumour development. These results on acoustic neuroma are consistent with an association with use of cellular phones. However, a recent study from Tokyo could not confirm an association. ${ }^{18}$ No case was reported with a latency period $\geqslant 10$ years.

Meningioma results were given in five case-control studies. $^{5} 10121415$ No consistent pattern of an association was found, although ipsilateral exposure in the $>10$-year latency group increased the risk in one of the studies. ${ }^{15}$ For a definite conclusion, longer follow-up studies are needed.

Results for glioma are given in nine studies (table 2). One was register-based ${ }^{7}$ and showed an increased risk associated with analogue phone use. The risk of glioma increased significantly per year of use. Six studies gave results for use of cell phone for $\geqslant 10$ years. For glioma, increased OR was found, which was more pronounced for ipsilateral use of the cell phone. This pattern of association was consistent in the various studies, except for the Danish study by Christensen et al. ${ }^{12}$ In that study, all 17 ORs for high-grade glioma were $<1.0$, indicating systematic bias in assessment of exposure. The Interphone $\operatorname{study}^{19}$ found a significantly decreased risk for glioma associated with mobile phone use, although the risk for ipsilateral use increased significantly with latency period and cumulative hours of use. As the authors discuss, the preventive overall result indicates methodological problems in the study. It is concluded that using $a \geqslant 10$-year latency period gives a consistent pattern of association between use of mobile phones and malignant brain tumours, especially high-grade glioma.

In spite of the heterogeneity ${ }^{21}$ between the different studies, we performed a meta-analysis for use of mobile phones with a latency period of $\geqslant 10$ years. We calculated OR for the whole group and for ipsilateral use of mobile phones. For both acoustic neuroma and glioma, OR was increased in the whole group, but significantly increased for ipsilateral exposure. No significantly increased risk was found for meningioma, although the highest OR was calculated for ipsilateral use. These results are certainly of biological relevance, as the highest risk was found for tumours in the most exposed area of the brain, using a latency period that is relevant in carcinogenesis. In another study, meta-analysis was performed on mobile phone use, yielding $\mathrm{OR}=1.0 \quad(95 \%$ CI 0.8 to 1.4$)$ for contralateral tumours and for ipsilateral tumours $\mathrm{OR}=1.3$ (0.99 to 1.9). No analysis was performed for $>10$-year latency time. ${ }^{21}$ Our findings stress the importance of longer follow-up to evaluate long-term health risks from mobile phone use.

The validity of short-term recall of mobile phone use was analysed in the Interphone study. ${ }^{22}$ It was concluded that actual use was underestimated by light users and overestimated by heavy users. There was a substantial heterogeneity between countries, and the inter-individual variation was larger, increasing with level of use. The authors stated that this large random error might reduce the power of the Interphone study to detect an increased risk of brain tumours. In a following article from the same study group, ${ }^{23}$ it was concluded that random recall bias could lead to substantial underestimation in the risk of brain tumours associated with mobile phone use. According to the authors, there was a selection bias in the Interphone study, resulting in under selection of unexposed controls with decreasing risk at low to moderate exposure levels. It was concluded that the validation studies would play an important role in the interpretation of the Interphone studies. It should be noted that some studies had a low response rate, especially among controls. Participants tended to be of higher socioeconomic status and therefore more likely to have used a mobile phone for prolonged periods of time.

We conclude that results from present studies on use of mobile phones for $\geqslant 10$ years give a consistent pattern of an 


\section{Main message}

- Results in case-control studies on brain tumours and use of mobile phones for $\geqslant 10$ years gave a consistent pattern of an increased risk for acoustic neuroma and glioma.

- Ipsilateral exposure (same side as the tumour occurred) yielded highest risk.

\section{Policy implications}

- These results indicate that the caution is needed in the use of mobile phones.

- More research is necessary for risk assessment based on higher number of long-term users.

increased risk for acoustic neuroma and glioma. The risk is highest for ipsilateral exposure. Longer follow-up is needed, however, as an increased risk for other types of brain tumours cannot be ruled out. From these studies, it is not clear at what stage microwaves act in carcinogenesis.

\section{ACKNOWLEDGEMENTS}

Supported by grants from Cancer- och Allergifonden and Örebro University Hospital Cancer Fund.

\footnotetext{
Authors' affiliations

Lennart Hardell, Department of Oncology, University Hospital, Örebro and Department of Natural Sciences, Örebro University, Örebro, Sweden Michael Carlberg, Department of Oncology, University Hospital, Örebro, Sweden

Fredrik Söderqvist, Department of Oncology, University Hospital and Institute of Clinical Medicine, Örebro University, Örebro, Sweden Kjell Hansson Mild, National Institute for Working Life, Umeå and Department of Natural Sciences, Örebro University, Örebro, Sweden L. Lloyd Morgan, Francisco Street, Berkeley, California, USA

Competing interests: none declared
}

\section{REFERENCES}

1 Hardell L, Näsman $\AA$, Påhlson A, et al. Use of cellular telephones and the risk for brain tumours: A case-control study. Int J Oncol 1999;15:113-16.

2 Hardell L, Hansson Mild K, Påhlson, et al. lonizing radiation, cellular telephones and the risk for brain tumours. Eur J Cancer Prev 2001; 10:523-9.

3 Muscat JE, Malkin MG, Thompson S, et al. Handheld cellular telephone use and risk of brain cancer. JAMA 2000;284:3001-7.

4 Johansen C, Boice JD Jr, McLaughlin JK, et al. Cellular telephones and cancer - a nationwide cohort study in Denmark. J Natl Cancer Inst 2001;93:203-7.

5 Inskip PD, Tarone RE, Hatch EE, et al. Cellular-telephone use and brain tumors. New Engl J Med 2001;344:79-86.

6 Muscat JE, Malkin MG, Shore RE, et al. Handheld cellular telephones and risk of acoustic neuroma Neurology 2002;58:1304-6.

7 Auvinen A, Hietanen M, Luukonen R, et al. Brain tumors and salivary gland cancers among cellular telephone users. Epidemiology 2002;13:356-9.

8 Lönn S, Ahlbom A, Hall P, et al. Mobile phone use and the risk of acoustic neuroma. Epidemiology 2004; 15:653-9.

9 Christensen HC, Schüz J, Kosteljanetz M, et al. Cellular telephone use and risk of acoustic neuroma. Am J Epidemiol 2004;159:277-83.

10 Lönn S, Ahlbom A, Hall P, et al. Long-term mobile phone use and brain tumor risk. Am J Epidemiol 2005;161:526-35.

11 Schoemaker MJ, Swerdlow AJ, Ahlbom A, et al. Mobile phone use and risk of acoustic neuroma: results of the Interphone case-control study in five North European countries. Br J Cancer 2005;93:842-8.

12 Christensen HC, Schüz J, Kosteljanetz M, et al. Cellular telephones and risk for brain tumors. A population-based, incident case-control study. Neurology 2005;64:1189-95.

13 Hepworth SJ, Schoemaker MJ, Muir KR, et al. Mobile phone use and risk of glioma in adults: case-control study. BMJ 2006;332:883-7.

14 Schüz J, Böhler E, Berg G, et al. Cellular phones, cordless phones, and the risks of glioma and meningioma (Interphone Study Group, Germany). Am J Epidemiol 2006; 163:512-20.

15 Hardell L, Carlberg M, Hansson Mild K. Pooled analysis of two case-control studies on the use of cellular and cordless telephones and the risk of benign brain tumours diagnosed during 1997-2003. Int J Oncol 2006;28:509-18.

16 Hardell L, Hansson Mild K, Carlberg M. Pooled analysis of two case-control studies on use of cellular and cordless telephones and the risk for malignant brain tumours diagnosed in 1997-2003. Int Arch Occup Environ Health 2006;79:630-9.

17 Schüz J, Jacobsen R, Olsen JH, et al. Cellular telephone use and cancer risks: update of a nationwide Danish cohort. J Natl Cancer Inst 2006;98:1707-13.

18 Takebayashi T, Akiba S, Kikuchi Y, et al. Mobile phone use and acoustic neuroma risk in Japan. Occup Environ Med 2006;63:802-7.

19 Lahkola A, Auvinen A, Raitanen J, et al. Mobile phone use and risk of glioma in 5 North European countries. Int J Cancer 2007;120:1769-75.

20 Hardell L, Hansson Mild K, Sandström M. Vestibular schwannoma, tinnitus and mobile telephones. Neuroepidemiology 2003;22:124-9.

21 Lahkola A, Tokola K, Auvinen A. Meta-analysis of mobile phone use and intracranial tumors. Scand J Work Environ Health 2006;32:171-7.

22 Vrijheid M, Cardis E, Armstrong BK, et al. Validation of short term recall of mobile phone use for the Interphone study. Occup Environ Med 2006;63:237-43.

23 Vriiheid M, Deltour I, Krewski D, et al. The effects of recall errors and selection bias in epidemiologic studies of mobile phone use and cancer risk. J Expo Sci Environ Epidemiol 2006; 16:371-84. 